\title{
6. James Salgado: Anti-Spanish Sentiment and the Popish Plot
}

\author{
Antonio Cortijo Ocaña
}

\begin{abstract}
The case of James Salgado, the Romish priest turned Protestant, is extremely interesting in the context of the Spanish Black Legend. Writing in the 1670 s and 1680 s, Salgado claims to be a Spanish ex-priest who was imprisoned by the Inquisition, served time rowing as a galley slave, escaped to Europe (France, the Low Countries), and finally arrived in England. Although his works contain anti-Spanish propaganda, his treatisedescription of bullfighting in particular includes numerous laudatory commentaries about Spanish culture that envision Spanish mores in a positive (or at least neutral) light. The ambiguity between the ideological and propagandistic purpose of his work and the author's origins reflects the nature of much pamphlet literature about Spain as both the land of romance and religious fanaticism.
\end{abstract}

Keywords: James Salgado, anti-Spanish propaganda, convert narratives, Popish Plot, Spanish manners

The case of James Salgado, 'the Romish priest turned Protestant' to use the title of one of his books, ${ }^{1}$ is extremely interesting for what it represents in the context of the Spanish Black Legend. James Salgado wrote in England several works of varied content in the late 1670 s and mostly the $168 \mathrm{os}^{2}$ These works belong to three distinct groups: religious tracts of a doctrinal nature, including an autobiographical account of

1 Usoz y Río and Wiffen (Reformistas antiguos españoles) are the first to refer to Salgado, see also Ménendez Pelayo, Historia de los Heteredoxos, vol. IV, pp. 195-198. See also Salgado, The Romish priest turn'd protestant with the reasons of his conversion.

2 See the 'Works Cited' for a complete list of his works.

Rodríguez Pérez, Y. (ed.), Literary Hispanophobia and Hispanophilia in Britain and the Low Countries (1550-1850). Amsterdam: Amsterdam University Press, 2020 DOI 10.5117/9789462989375_CHo6 
his sufferings at the hands of the Inquisition, in which he extols the virtues of Protestantism and exposes the fanaticism of Catholicism; secondly, accounts of Spanish customs and mores that fluctuate between the festive and the ethnographical, centred among the major topics of the Inquisition and bullfighting, and lastly, more fanciful work of a literary nature that includes narratives whose main characters are Catholic priests and nuns.According to his autobiographical accounts, Salgado claims to be a Spanish ex-priest (Dominican) who was imprisoned by the Inquisition, served his time rowing as a galley slave, escaped to Europe (France, the Low Countries) twice, and finally made his way to England during a time span that covers some 20 years around $1660-1680$. In his The Slaughter-House, a description of the Spanish Inquisition, he writes about himself:

A Spaniard by Birth and with my Mothers Milk I suck'd in the Romish Religion; and at length was Ordained Priest. Discerning at last the vanities and multitude of the Superstitions of the Roman Faction, thro' the healing influence of the heavenly Illumination, I was cured, and came to the Reformed. ${ }^{3}$

Once in the free Albion, Salgado devotes his life to writing about his experiences, either proclaiming his new (Protestant) faith (abjuring Catholic practices and superstitions) or explaining to his English audience the barbaric customs of the Spanish nation (Inquisition, bullfighting, etc.). His views offer his readers the interesting opinion of the convert, modelled in great part after the example of Saint Paul. ${ }^{4}$ But more interestingly, they provide credibility, reliability and objectivity because he is a first-hand witness of Spanish atrocities: a Spaniard who knows intimately well the topic he writes about. His descriptions of Spanish mores are supposed to not be tainted by foreign misunderstandings or partial knowledge of another country's traditions. In sum, Salgado offers his accusations as unimpugnable testimony.

Nevertheless, things are not that simple. First, scholars have not been able to find any documentation whatsoever pertaining to 'James Salgado'. Second, his life experiences have the familiar taste of other biographical accounts (some of them purportedly imaginary), such as those of Juan de Nicolás, Melchor Román y Ferrer, and Fernando de Tejeda (real name Tomás 
Carrascón), ${ }^{5}$ which could lead us to believe that his writings belong to a genre and are not entirely an autobiographical account. ${ }^{6}$ Finally, his decidedly anti-Jesuit penchant and the English context in which to place it point to the fact that 'James Salgado' might well be a nom de plume utilized by someone to write anti-Catholic and anti-Spanish propaganda from England. Against this backdrop, this chapter will delve into some of Salgado's works and his attitudes towards things Spanish. Although his works are clearly part of anti-Spanish propaganda, in particular his treatise-description of bullfighting contains numerous laudatory commentaries about Spanish culture that envision Spanish mores in a positive (or neutral, at least) light. The ambiguity between the ideological and propagandistic purpose of his work and the author's origins reflects the nature of much pamphlet literature about Spain as both the land of romance and religious fanaticism.

\section{Salgado's biographical account}

The beginning of the $20^{\text {th }}$ short narrative included in The Fryer (London, 1679) makes Salgado's anti-Jesuit inclinations clear to the reader:

We have been long enough Expatiating in the Gardens of several Countries, and Collected many Flowers (though not altogether well smelling) for our Pastime and Diversion; now leaving off to transport them any more at present out of Forreign parts, will see if there be none of our own Plantation here in England, which may be as delightful as the rest. And indeed should tend to the prejudice of Jesuits and Fryers, if they should exempt only England from their deluding Tricks, a Country so plentiful, and having store of all, to the very Superfluity. Therefore to free them from such a Scandalous Aspersion, I'le [sic] relate to the kind Reader, a History, which not long since hapned here in England, and above the rest, in the Famous City of London. And it is about two Priests, the one being a Jesuit, and the other a Carmelitan Fryer. ${ }^{7}$ (Emphasis added)

5 Centro de Estudios de la Reforma, 'Protestantes'.

6 We can remember that Miguel de Montserrate, another famous Spanish convert, uses excerpts of Casiodoro de la Reina's account in his own narrative, as pointed out by Menéndez Pelayo: 'Montserrate era un insolente plagiario; trozos hay en su dedicatoria copiados ad pedem litterae de la Amonestación que puso Casiodoro al frente de su Biblia' (Montserrate was an insolent plagiarist; there are parts of his dedicatory taken ad pedem litterae from the Amonestación written as a prologue to his Bible by Casiodoro de la Reina). See Menéndez Pelayo, Historia de los heterodoxos españoles, vol. 2, p. 159.

7 Salgado, The Fryer, pp. 183-184. 
As we will later contend, The Fryer (more than any other of Salgado's works) must be understood in a moment of anti-Catholic anxiety and portrays for English society the embodiment of the evil nature of Catholicism. In particular, Catholic priests and Jesuits, according to the book, can jeopardize the political integrity of the nation as milites Christi. In their connection with Spain, they are an extension of this country's fanaticism and the religious counterpart to Spain's desire for universal domain. The political and the religious are thus inextricably entwined in the Jesuit order, which must be combated at all costs.

Salgado's works present at times a devastating picture of Spain. They seem to offer English readers a faithful representation of Spanish customs and traditions, although they are nothing more than partisan pamphlets. Salgado's confession stands as a case in point. Following in the footsteps of previous Spanish converts (such as Juan Díaz, Francisco de Enzinas, Antonio del Corro, Casiodoro de la Reina or Cipriano de Valera), Salgado, the Dominican priest, experiences an episode of religious doubt or conversion motivated by a biblical passage that makes him see his faith in a new light. As he expresses in A Confession of Faith (1681)

'Tis very true, that the Romanists debat the Common People from reading the Holy Scriptures, as from the Food of Life; but yet those of the Clergy (and that especially in Spain, my Native Country) as well as other Roman Catholicks are wont more Religiously to exercise themselves in Reading the Sacred Scriptures. The same thing happened to me also; and while I was Reading Gods Holy Book, I lighted upon those words of the Apostle, 2 Tim. 3:16: All Scripture is given by Divine Inspiration, and is profitable for Doctrine, for Reproof, for Correction, and for Instruction in Righteousness: That the Man of GOD may be perfect throughly furnished unto all good Works.

According to Salgado, upon this revelation following the reading of 2 Tim. 3:16, he feels that he is not free to exercise the power of his reason within the strict constraints of Spanish religious, Catholic fanaticism. Obliged to leave Spain and once in the safe haven of England, after stays in France, the Low Countries

8 See Cortijo Ocaña, Herejía, for a detailed analysis of Salgado's works in the context of the Spanish Black Legend and the anti-Jesuit sentiment in England. Some of the notes here come from this monographic study. On readers and Reformation in Spain, see also Wagner, 'Los maestros Gil de Fuentes y Alonso de Escobar', and 'Erasmistas y reformistas'; García Pinilla, 'Lectores y lectura clandestina'. 
and possibly in Italy, Salgado provides the academic senate members of the University of Oxford with 'AN / ACCOUNT / OF MY / LIFE \& SUFFERINGS / Since I forsook the / ROMISH RELIGION; / IN A / Letter to Dr. H.S.' The document encapsulates some of the major themes of Salgado's discourse: Spanish fanaticism (represented by the Inquisition); Spanish cruelty (represented by the American conquest); Spanish Islamicism (represented by bullfighting), etc. ${ }^{9}$ :<smiles>[AlH2]</smiles>

The first thing that startled me, and made me withdraw from the Covent, in which I had lived in Priests Orders three years, was the dissention betwixt the Popish Doctors themselves, and that in such things as themselves say Salvation depends upon: for whilst some of them make it necessary to Salvation to believe that the Church is (infallibly) govern'd by [2] the Holy Ghost, and therefore the ultimate Resolution of Faith must be the Determinations of the Church: I found others did doubt of this and dispute against it.

Whilst I was thus laying things together in my mind, \& under great dissatisfaction, I resolved to leave Spain (my Native Country) and go into France where I hoped for greater freedom of speech: for at home I found it most dangerous to move any thing (how modestly soover) against received Points. Coming then to Paris, I had many hot Disputes with those of my own Order, with as little satisfaction, as in Spain. But at last I betook my self to some of the Ministers of the Church at Charenton, ${ }^{10}$ by whom I was very Christianly entertained, and amongst them the Reverend Monsieur Drelincourt, took great pains to answer my doubts, and I came forward to close with the Truths of the Reformed Religion, and he was concern'd for my safety, and advised me forthwith to go into the United Provinces: But first I had in their Consistory renounced Popery, viz. anno, $1666 .{ }^{11}$

When I was come to the Hague, I had a most courteous reception by that Excellent Person Monsieur Samuel Maretz ${ }^{12}$ : he used his endeavour

9 To all the Singular Members of the University of OXFORD. To the Reverend, and most Excellent, Mr. Vicechancellour. To the Reverend and Eminent Heads of Colledges. And to the Worthy Fellows of the fame.

10 See, for instance, The generall and particular acts and articles of the late national synod of the reformed Churches of France (1644).

11 Charles Drelincourt was a Calvinist pastor at Charenton, 1595-1669. See his Les derniéres heures de Mr Drelincourt, decedé à Paris le 3. Novembre 1669.

12 Samuel Desmarets was born in Picardie and ordained as pastor in the Netherlands (Groningen). He was the author of a book attacking the Pope and the Jesuits. 
to settle me there, and for my livelihood put me upon the teaching the Spanish Tongue: But when that could not succeed, because of my ignorance of the Dutch Language (although I was well enough able to teach those that understood Latin, French, or Italian), he gave me advice to return to Paris.

There I was forced to lye privately amongst the [three] Members of the Reformed Church, being afraid to be known to others: But the Queen of France, ${ }^{13}$ a Spaniard by Birth, had brought over with her many of her Country men, who too well knew me, and narrowly enquired after me. By their means I was taken, sent back into Spain, put into the Inquisition in the Province of Estremadura, and the City of Llerena: there I lay a year, and was monthly examined, but at last made an escape.

When I had gone almost a hundred Leagues, as far as Origuela, I was laid hold on by the Fryers of my own Order, and sent by them to Murcia, where I lay five years in Prison, having neither Books, nor Society, except of tormenting Priests.

I was at last brought before the Bishop, and other Officers of his Court, where for the Scandal, as they call'd it, I had given, I was sentenced to the Galleys. When they had publickly read my Crime, during which time they made me hold a Black Candle in my Hand, the Sentence was executed upon me.

In the Galleys, for a year's space, I endured the miseries that attend Slaves at the Oar, Chains, Nakedness, Stripes, Thirst, Hunger, Vermine, and Sickness, which they termed a Leprosie, till at length the Chyrurgion and other Officers of the Galley where I was, interceded with the Inquisitor General for me, as a person not only useless, but noysome to them and the other Slaves. He hereupon sent me into the Hospital at Murcia; after my Cure, I stayed some months, in the Convent, but never returned to my Habit, because my Impenitence, as they termed it, hindered my Absolution.

[4] From thence I made a second escape into France, and after I had stayed about a year at Lion, not finding my self safe, I came into England: what assistance I have had here both to establish me in the Reformed Religion, and for my subsistance you well know. Other passages Historical which are in my Confession I here omit; Likewise what thoughts it pleased God to comfort me with, in my distresses, what temptations I endured, and how through the Grace of God, I overcame

13 María Teresa de Austria y Borbón (1638-1683) was the daughter of Felipe I of Spain and Elisabeth of France (Bourbon). She became queen consort of France in 1660 after marrying Louis XIV of France. 
them, I cannot in the narrow room of this Leaf set down; neither had thus much of me ever come in Print, but at your request: and if any doubt be made of these things, you, or any others, that have Correspondent about Murcia, may please to satisfie your selves as to a considerable part of them: To this then I refer you, and am, Sir, Yours. James Salgado. FINIS.

In a serious vein Salgado produced a theological tract entitled The true church of Christ exposed to the view of all sober Christians, from the Word of God, sound reason, and the ancient fathers / by James Salgado, a Spaniard, a converted priest (London, 1681). To some extent, this work must be read together with his previous autobiographical account. In it, the ex-priest rejects the Catholic claim to the universality of the Roman Church and the assertion of papal infallibility, as well as their accusation of Protestants as schismatic and heretical. He concludes by thanking almighty God for making him see the truth and beseeching his readers to reject Catholic abomination and 'embrace the true Protestant Religion, which is pure in Doctrine, holy in manners, and faithful to God and the King'.

While a study of Salgado's works must begin with his confession of faith, a self-justification of his religious discontent and defection from the Catholic creed, his oeuvre as a whole strikes multiple chords. For instance, his books are interspersed with numerous references to and anthropological and cultural comments on Spanish traditions, character, and mores, making them rather unusual. We perceive in many of them an attempt to conflate religion and politics, showing the inescapable parallels between the tenets of the Protestant Reformation against Catholicism and the European political situation with regard to the theory of dominium mundi of which the Spanish Empire was accused. Thus, he claims, in the same way that there is no Universal Church, for all churches are parts or members of the body called Christendom, he also argues that no empire (that is, the Spanish Empire) can claim universal dominium over Europe (and the world). If the church at Rome is only one among many, then the Spanish Empire, by the same logic, should be only one among several. The Spanish desire to dominate other nations can be conflated with the Roman Church's desire to dominate the Christian world. But let us remark once again, while this could be the ultimate raison d'être of Salgado's oeuvre, he touches here and there upon numerous topics and genres in his diatribes against Spain which go beyond what we could term exclusively religious criticism. 


\section{Spanish manners and customs}

That is the case with the next two works we will be dealing with: The manners and customs of the principal nations of Europe (London, 1684) and An Impartial and Brief Description of the Plaza, or sumptuous Market Place of Madrid, and the Bull-fighting there (London, 1683). The manners and customs of the principal nations of Europe gathered together by the particular observation of James Salgado [...] in his travels through those countries; and translated into English by the authors care, was published in London by T. Snowden in 1684 (reprinted in 1685 in Edinburgh by Josua van Solingen and John Colmar, with minor variants). Adopting an ironic and humorous tone, Salgado compares Germans, Italians, French, English and Spaniards. In this comparison, Spaniards stand always at the losing end, as they are characterized by negative traits such as their precaution, silence and deceitfulness, their short size, grandiloquence, vengeance, pride, blind obedience, hypocrisy, cruelty and tyranny. It is nothing but distorted satire, nonetheless interesting because it feeds the English imagination with its own biases:

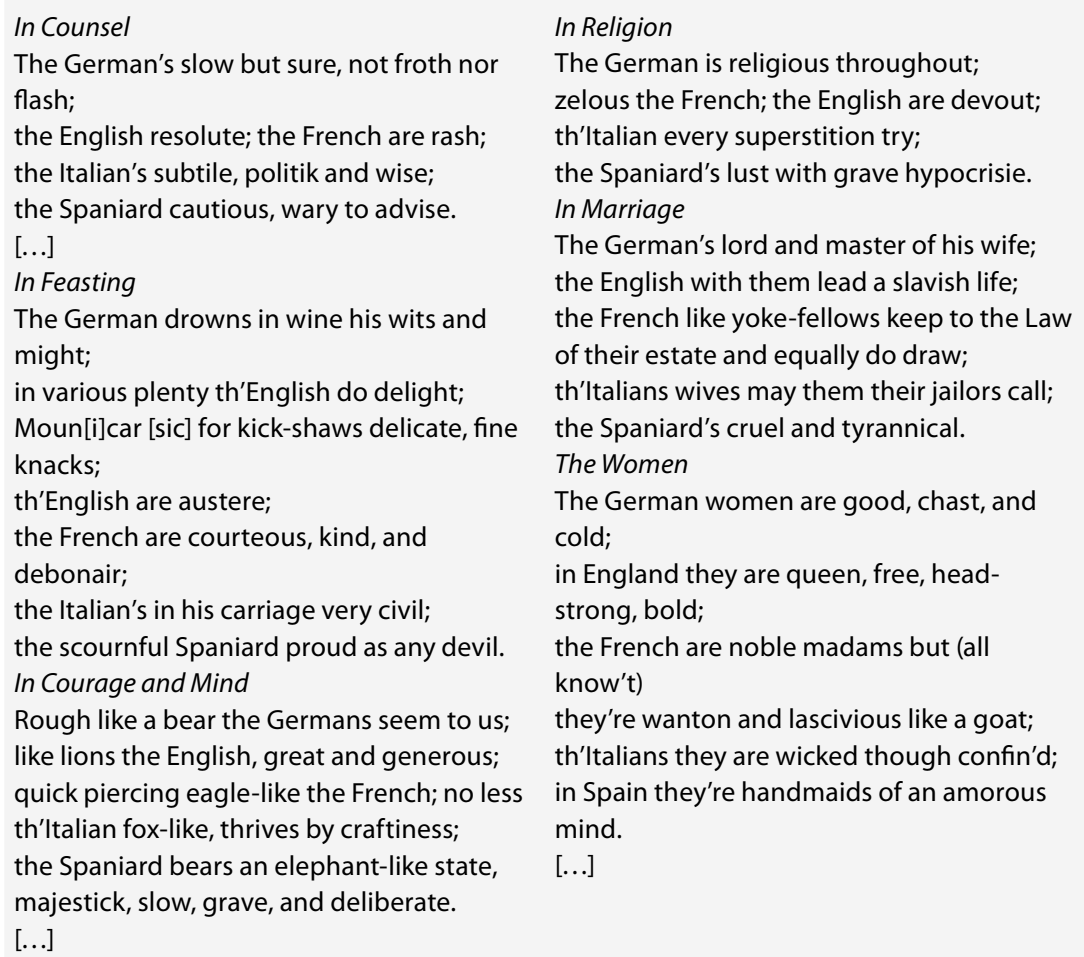




\section{In Presence}

The German is a sot, so speak his eyes; the English looks not over fool nor wise; the French seems mad yet sew their wit can scan;

the Italian seems and is a prudent man; but formal Spaniard with's deep gravity would fain seem wise yet none more fool than he.

\section{In Laws}

The Germans laws are rigid and severe yet towards these they strict observance bear;

France to good laws gives no obedience due;

the English still are hankering after new; the Italians have good laws which they observe; the Spaniards from nor good nor bad dare swerve.

\section{In Civil Business and Meetings}

The German well begins, concludes amiss; the English man wedded to his judgement is;

the French capricious, windy, giddy, vain; the Italian shows he has a politick brain; but various the conditions of Spain.

\section{In Merchandizing}

The German care at last, at first neglect; gain puffs not th'English nor does loss deject; French covet all if without any pain; th'Italian well doth weigh his loss and pain; the Spaniard never did great seats in trade because to venture far he is afraid.

[...]

This taxonomy presents us with a puzzling question about its degree of anti-Spanish sentiment. While many of the traits that characterize the Spaniard are negative, some others are rather positive or neutral, or at least should be put in the context of other negative traits mentioned for the other nations. What is curious is that the composition reads almost like a typical contemporary joke in which a nation or persons from a particular region are derided as unlearned, unsophisticated, or utterly stupid in comparison with people from other regions/countries. As the structure suggests, the region/country ridiculed is left as the last term of the comparison, as if a logical corollary were to be deduced from the syllogism suggested by the joke. The fact that the composition resembles this typical satirical structure seems to indicate that the main purpose of the piece is to present a negative view of Spain/Spaniards. In any event, we should take into account that there is also a festive attitude that permeates the whole composition, which could be seen as a rhetorical exercise rather than a piece of anti-Spanish propaganda. We must also bear in mind that this type of composition, based on a comparison of national characters or on a description of the characters of a single nation, began to develop in the last decades of the sixteenth century and in the early seventeenth century. Ultimately, the genre derives from the late medieval humanist discourses in praise of national character, which included compositions commending cities and countries. It then moved 
on to literary pieces that compared nations. While some of these works were rather festive and humorous, others were in a serious vein, as was the case of John Stephens's Essayes and Characters (1615) - in line with the famous Characters by Sir Thomas Overbury (1614-1616), which dealt with the national English character and included as part of his description of a farmer a rather puzzling mention of his hatred of Spain: 'He cannot therefore choose but hate a Spaniard likewise, and (he thinks) that hatred only makes him a loyal subject.' ${ }^{14}$

In any event, in the context of Salgado's entire production, the work could be read as part of his varied sets of strategies to criticize Spain or comment negatively on the Spanish character, which will later also adopt a fanciful and literary form in The Fryer (see below). While we could perceive some anti-Spanish zeal in The manners and customs, moderated by the fact that humour permeated the entire composition and that it was intent on extolling English virtues more than criticizing others' faults, the second work is of a very different nature: An Impartial and Brief Description of the Plaza, or sumptuous Market Place of Madrid, and the Bull-fighting there (London, 1683), addressed to King Charles II.

Again, the fact that it was addressed to a Hispanophile monarch leaves us with some pressing questions. Under the guise of offering an objective description of bullfighting, Salgado provides his readers with a tainted interpretation of a custom he considers barbaric and representative of Spain's 'Islamic' past, which he does not want associated with 'Romantick Novelties' ('in regard that I hear no liking to disingenuity, or the forging of Romantick Novelties and Fictions') but with the people who have previously inhabited Iberia ('Romans, Vandals, Goths and Saracens', 'of the frequent, and noisome In-roads of many Cruel Adversaries of different Languages, Laws and Constitutions, so that some Vestigias [sic] of the one must be supposed to remain, as well as the other'). ${ }^{15}$ And he adds further: 'The Saracens obtaining the latests Conquest, their Laws and Language leave the deepest Impression. ${ }^{16}$ The spectacle in the stands mimics the spectacle in the arena, an affair based on the ideas of honour and danger that befits the primitive and Orientalizing nature of the Spaniard. 'Cruel and Barbarous Recreation' is to be expected from 'such a Barbarous Rable as the Turks were and are to this day': 
Figure 6.1 An Impartial and Brief Description of the Plaza (London: Printed by Francis Clarke for the Author, 1683), p. 8

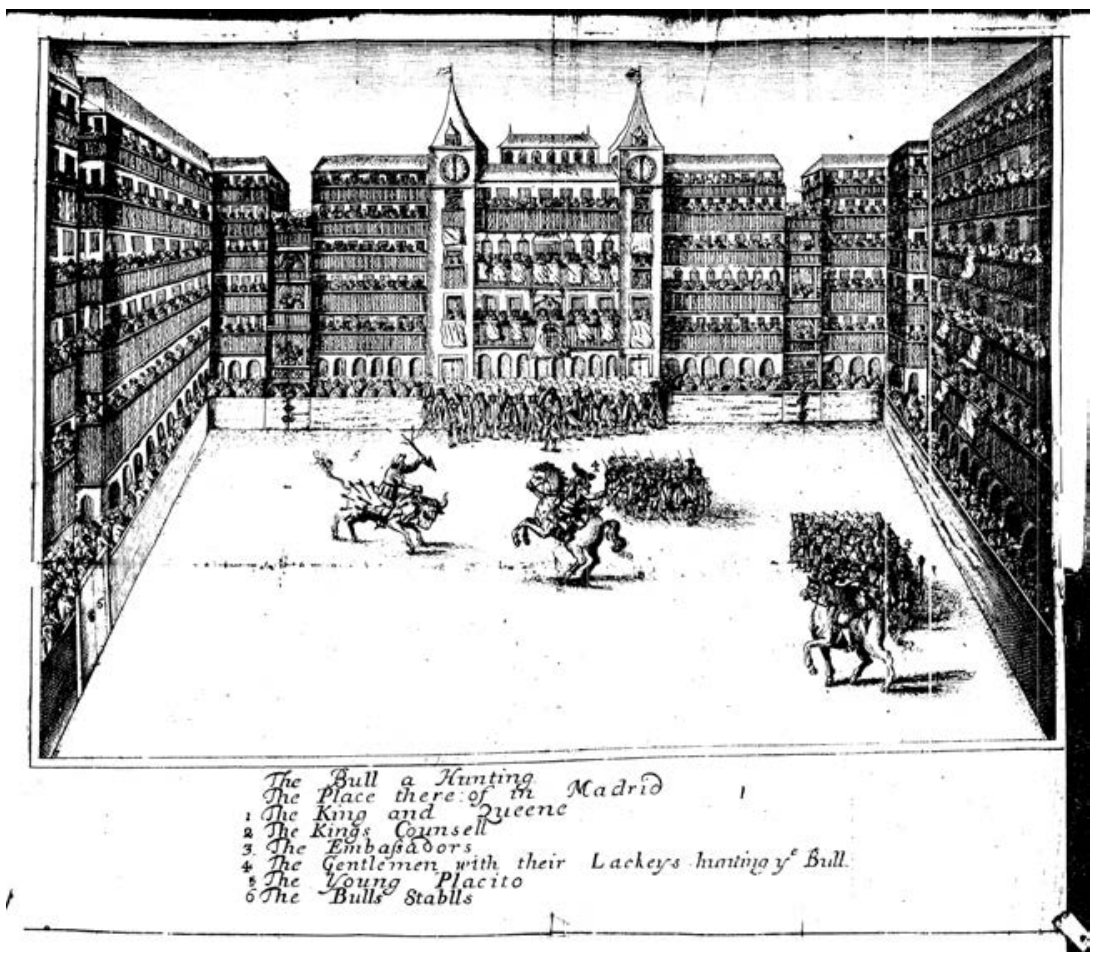

Courtesy Calambur

It's a thirsting desire after some imaginary Honour that sets such Bold Fellows upon the exposing of themselves to those dangerous circumstances, rather than the advantage of getting the Beasts which they have Killed, or Wounded to purpose. ${ }^{17}$

The book also includes references to Charles I's visit to Madrid as Prince of Wales in 1623, the many comedies, plays and festivals performed in his honour and the toros. His general and perfunctory assessment of the entertainment is that 'it is a recreation scarcely beseeming Christian' and that Christian humility and nobility should forbid it. Nonetheless, participants must be graceful and agile, and while Roman spectacles were designed to satisfy 'the Bloody and Vindictive Humours of the people, who rejoyced in such 
lamentable experiments', in bullfighting nobody is obliged to fight nor are criminals punished: 'but Masculine and Noble Minds desire an occasion of this kind, whereby proof may be given of their Agility and Undaunted Courage ${ }^{18}$ His conclusion is that he is only intent on describing, not criticizing it ('which is judg'd in Spain a most Noble Recreation'). If the festive intention characterized the The manners and customs as well as a sporadic penchant for a fair description, this positive light of things Spanish also appears in $A n$ Impartial and Brief Description. We have perceived in the latter an intent to go beyond the anecdotal. Although the final message is clear (a depiction of the Spanish custom of bullfighting as 'scarcely beseeming Christian'), Salgado strikes a more nuanced view of this and other Spanish customs.

A negative view of the Spanish character is further reinforced in Salgado's description of the practices of the Inquisition in The Slaughter-House; or, A brief description of the Spanish Inquisition, in a method never before used in which is laid open the tyranny, insolence, perfidiousness, and barbarous cruelty of that tribunal (London, 1682). The work follows the tradition of writings about the Spanish Inquisition by Spanish converts, which started with the Confesión de fe cristiana (hecha por ciertos españoles, los cuales, huyendo de los abusos de la Iglesia Romana y la crueldad de la Inquisición de España, dejaron su patria para ser recibidos de la Iglesia de los fieles por hermanos en Cristo) by Casiodoro de la Reina (London, 1560) and particularly Sanctae Inquisitionis Hispanicae artes aliquot detectae, ac palam traductae (Heidelberg, 1567) by Reginaldus Gonsalvius Montanus, that is, Antonio del Corro. ${ }^{19}$ Salgado provides an autobiographical account of his suffering at the hands of the Inquisition, his escapes and his time as a galley slave. ${ }^{20} \mathrm{He}$ offers a detailed description of an auto-da-fé, including the contributions of familiars, sergeants, consultors, qualificators, notaries, secretaries and

\footnotetext{
18 Ibid., p. 17.

19 Roldan-Figueroa, 'Antonio del Corro'.

20 Salgado, The Slaughter-House, pp. 7-8: 'After one years Imprisonment, weary of it, and earnestly desirous of liberty, I attempted to get loose by flight; but after I was gotten near one hundred Leagues from Lerina, and had reached the City Origneleno, the Officers of the Inquisicion seized me again, and sent me into the Inquisition at Murcia. Here for a new Crime, which was my Escape from the holy Inquisition, I was five years imprisoned, where I had neither Books, nor any Light, nor company of any man, but the bloudy Inquisitors, and their Slaugther-men.' As for the galley slave, he claims that there is no punishment 'more grievous than these toils are to any man unaccustomed to them. In the effect appeared the cruelty of their usage, for it soon made me a Leper, and unfit for labour. I was extremely pined, and consumed away, and (which I blush to speak) so great a multitude of Lice swarmed about me, that I might be excused, if I thought I felt one of Egypts Plagues. And though I was kept in greatest scarcity of meat and drink, which ordinarily cause sweat, yet a perpetual sweat fell from my whole Body, which (if it offended not your Ears) turned into most stinking worms.'
} 
fiscals of the tribunal, and of the lack of procedural warranties for the accused:

First they apprehend a man as a Jew, a Mahumetan, or Reformed, thrust him into Prison, without telling him who, or how many accuse him: Next he suffers the miseries of this Imprisonment six or eight, or ten years; if at last the man, to get put off their hands, confesseth all deposed against him to be true; and implores their mercy; then the Inquisitors proceed to enquire whether he knew his Accusers. The poor man (as is truth) answers he knows them not; hereupon (though he confess, and sue for mercy) yet he is burnt, because he knows neither persons, nor names of his Accusers. Here oftentimes it happens, that the man, because he will not die unrevenged, and without company, accuseth a whole Village or Town, that amongst them he may hit the Persons that accused. ${ }^{21}$

References to the Inquisition abound in Salgado's work, for the institution represented the main accusation for the case of Spanish fanaticism and cruelty. In this work, Salgado concludes by listing several inquisitorial cases of the 1640 - 166 os and calling the Inquisition a 'Devil's villainy' that cries out for vengeance to destroy 'those murtherers'. While the atrocities of the Inquisition resemble what had been published previously in many works, the list of inquisitorial cases adds a documentary element to Salgado's book. As with his description of bullfighting, Salgado seems intent on proving his assertions either by referring to his first-hand experience as a Spaniard or by utilizing documentary evidence that points towards his self-construction as an objective narrator. Salgado's work as a whole represents a conscious attempt to build a case against Spain. In doing so, the author uses a variety of genres and registers, from the comic and festive to the serious, documentary, and doctrinal. It almost seems as if nothing escaped his interest in trying to depict Spain and Spanish customs to an English audience, building almost element by element a solid and robust case against his nation of origin.

\section{The Fryer}

Very different in nature is The Fryer; or, An historical treatise wherein the idle lives, vitiousness, malice, folly, and cruelty of the fryers is described: in two parts, tragical and comical, published in 1680, a collection of novellas of Boccaccian taste centred around the figures of dissolute and deceitful friars, 
nuns and priests. ${ }^{22}$ Most of the stories in The Fryer are translations from the Decameron, Margarite of Navarre's Heptameron or François de Rosset's Histoires tragiques de nostre temps, as well as Céspedes y Meneses's El español Gerardo. Particularly relevant is the latter title, for it shows a knowledge of Spanish literary fashion at the time. While many of the works utilized as sources for the composition had a wide dissemination in Europe, it is possible that the author learned about them in Spain, where these narratives enjoyed a particular relevance. While true religion, he says to the Duke of Monmouth and Buclough to whom he addresses his work, 'ought to have the highest Encomium', the opposite should be predicated of the characters that follow, whose actions represent 'cunning knavery', which should serve as a caution to Catholics because they 'hazard themselves in the power of such Persons'. Throughout the work we meet a wide variety of friars and priests, many of them related to the Inquisition, all of whom could represent Salgado's dealings with this institution in Spain. Nevertheless, the Jesuits bear the weight of the invective and criticism, a fact that we could use to further analyse the motivation behind Salgado's writings.

The Fryer has a rather unique status among Salgado's works. It shows a superb knowledge of popular and successful narratives with wide circulation throughout Europe, already anticipated by the History of Placidus in his The Slaughter-House. It could also be posited that Salgado uses the wide dissemination of these types of narratives in Spain (and the fact that many of them had been translated into English) in order to offer a rather tendentious selection of these narratives with the ulterior motive of painting a devastating picture of the religious group as hypocritical, deceiving and inauthentic.

Who is then James Salgado? Although his work is full of biographical data, on a closer look none of the facts he mentions allows us to identify a single relevant aspect of his life from a documentary point of view. His details about life in Spain are of a general character, accessible to anyone who

22 This penchant for Italianate narrative work had already been anticipated by the History of Placidus, a novel introduced in the second part of The Slaughter-House. There, Salgado recounts the story of Placidus, which takes place between Italy and Spain. The relationship between the description of bullfighting and Placidus is somewhat tenuous. Placidus, upon his arrival in Spain, finds himself fighting a toro. Maybe more interesting is the description of the many cloak-and-dagger adventures in which he engages (in Venice, Madrid, etc.) and which are somewhat reminiscent of some of the events described in the accounts of the Prince of Wales's visit to Spain in 1623. See, for instance, the anonymous The High and mighty prince Charles, Prince of Wales, \&c.; and a translation of Juan Antonio de la Peña's work, entitled A relation of the royall festiuities and juego de cañas (a turnament of darting with reedes after the manner of Spaine) made by the King of Spaine at Madrid. 
lived in Spain during his time or had access to people or publications from this country. His descriptions of bullfighting and of the Inquisition do not reveal anything new or reflect an exclusively autobiographical perspective. Even his reference to the persons that welcomed him in France and the Netherlands do not imply that he had personal knowledge of them because the details or facts about their lives that he mentions in his writings are rather vague. Finally, a work like The Fryer, composed of translations of previously existing material, points to the same reality. Could we be facing then a literary persona as opposed to a real author? Could Salgado be a nom de plume behind which we might suspect a person or persons cognizant about Spain, possibly even a Spaniard or Spaniards living in England at the time? And if so, what could be the reason behind this procedure? The latter question might have a possible answer. While it is true that we could suspect that the real author(s) behind Salgado's name might have feared repercussions should his identity become public, it is possible to think that an autobiographical device could lend credibility to a detailed account of Spanish life, as does the fact that Salgado claimed to have been a priest. Would it not be understandable that an ex-priest knew religious life in Spain in all its details? Would it not make sense that, fearing the Inquisition, he tried to hide his real identity? Would it not make sense that he tried to caution his English readership about the deceitfulness of Catholic hypocrisy because he has known it first-hand?

Nonetheless, the historical context might allow us to shed some light on the Salgado conundrum. Between 1678 and 1681 England endured one of the frequent sixteenth-century rebirths of anti-Catholic sentiment, a recurring fact since Elizabethan England. ${ }^{23}$ In particular, Titus Oates (who had studied in a Jesuit seminary) and Israel Tongue devised the so-called Popish Plot. As a result, more than 500 Jesuits were denounced to the Privy Council, as well as countless members of the Catholic clergy and nobility (in particular, William Herbert, Henry Arundell, William Petre, William Howard and John Belasyse). The death in 1678 of Sir Edmund Berry Godfrey under suspicious circumstances gave credibility to Oates's accusations. Turmoil ensued. The memory of the Gunpowder Plot of 1605 reminded people of the danger of Catholic and Jesuit conspiracies. According to Claude de la Colombière, who was then residing in London "the name of "Jesuit" is hated above all else - even by priests both secular and regular, and by the [C]atholic layfolk

23 Bossy, The English Catholic Community; Holmes, Resistance and Compromise; Pritchard, Catholic Loyalism in Elizabethan England; Trimble, The Catholic Laity in the Elizabethan England. See also Cortijo Ocaña and Gómez Moreno, Bernardino de Mendoza. 
as well, because it is said that the Jesuits have caused this raging storm'. Indeed, the Pope-burning procession of 1680 claimed that 'a Jesuit can do nothing but whats ill'. ${ }^{24}$ The Popish Plot provoked a rebirth of English anxiety about both Catholicism as treason and Spain as the arch-enemy of England. While some monarchs might have entertained Hispanophile tendencies, it is clear that anti-Spanish sentiment ran deep.

Catholics endured several punishments as well as imprisonment, and were forbidden from participating in the Parliament (a measure somewhat reduced in 1788 with the Papist Acts but not abolished until 1829 with the Roman Catholic Relief Act). As a direct consequence of the Popery Act ('Act for the Further Preventing the Growth of Popery') there were numerous acts of vandalism directed towards Catholics in 1698-1700 as well as protests against the act, including a march of 6o,0oo people on Parliament. Menéndez Pelayo suspects the authenticity of the writings of several Spanish Protestant authors (such as those of Sacharles, Román y Ferrer, etc.). It would be advisable to consider Salgado a fictitious name, for now. As a pamphleteer whose books focus on denigrating Spain and Catholicism, and the Jesuit order, in particular, Salgado's views are reinforced by the fact that he claims to be a Spanish ex-priest persecuted by the Inquisition and who fled to the safe haven of Protestantism in England. His (pseudo)autobiographical works serve as a cautionary account that explains to his English audience the danger of Papist practices and beliefs and warns them of the brutality and fanaticism of the Spanish Empire. The Popish Plot, in this context, could be seen, in the internal logic of Salgado's works, as just one more proof of his statements, which required immediate and swift action on the part of authorities lest the English body politic should be permanently infected. In fact, a brief review of the many anti-Jesuit books published in England around the time or as a direct consequence of the Popish Plot makes clear that the threat was felt as very real by many. ${ }^{25}$

24 Maguire, 'Factionary Politics', p. 82.

25 The rather large number of books and pamphlets published in England about Jesuits or the Jesuit Plot between 1679 and 1681 (we have identified over a hundred titles) is symptomatic of the threat felt by English society. For instance, we could mention the anonymous The true narrative of the procedings [sic] at the Sessions-House in the Old-Bayly; or, The trial and condemnation of six notorious popish priests \& Jesuites, for high-treason viz., William Russel alias Napper, James Corker, Lionel Anderson alias Munson, Charles Parry, and Alexander Lunsden, at a commission of Oyer and Terminer there held, on Saturday the $17^{\text {th }}$ of this instant January 1679 (London, 1679); E.G., The horrid, direful, prodigious and diabolical practice of the Jesuits discovered fully laying open the means, manner and circumstances whereby they inveagle and seduce inhumanely some unwary Protestants to the utter ruine and damnation of their souls (London: Printed for A.C., 1679); Anon., A Full Narrative; or, A discovery of the priests and Jesuites; together with their intrigues 
Salgado's work is thus part of a very concrete context, that of the England of the second half of the seventeenth century and the power struggle among different factions. His works might have been mostly motivated by the real or imaginary Popish Plot supposedly organized by Jesuits (or at least masterminded by them). This was nothing new, because ever since the end of the sixteenth century Jesuits, in their connection with Rome and in particular with Spain, were constructed in England as a political concern regarding the interference of a foreign power in English affairs. Catholicism became thus a crime of political treason. In the context of Salgado's works, this sixteenth-century historical construction is re-utilized to demonize a seventeenth-century political opponent, appealing to the connection between Jesuits and Spain. Nevertheless, his work also reflects at times a more neutral tone regarding Spain that might make us suspect that we are dealing with a rhetorical device more than a truly heartfelt attitude. ${ }^{26}$ Of course, identifying the real identity behind Salgado's name would help us resolve the puzzle.

In sum, although anti-Spanish sentiment in England underwent many changes and nuances after the time of Queen Elizabeth, for many, Spain never ceased to represent in the English imaginary a threat to the nation's

how to subvert Protestant princes, and to ruine the Protestant religion as it is now established. In which is plainly demonstrated the effects of their political operations upon us at this day, in respect of religion and matters of state: together with the necessity of their banishment ([London], 1679); Ezerel Tonge, Jesuits Assassins; or, The Popish plot further declared and demonstrated in their murderous practices \& principles the first part [...] / all extracted out of Dr. Tong's papers, written at his first discovery of this plot to his Majesty, and since in part augmented for publick satisfaction (London: Printed by J. Darby to be sold by the Booksellers, 1680); Richard Greene, The popish massacre as it was discovered to the honorable House of Commons, sitting in a grand committee for the suppression of popery, in the month of June 1678 at the time of the Parliaments prorogation (London: Printed by T.D. for John Smith, 1679); Anon., A moderate expedient for preventing of popery and the more effectual suppression of Jesuits and priests, without giving them the vain-glory of pretending to martyrdom ([London?, 1680]); N.N., The arts and pernicious designs of Rome wherein is shewn what are the aims of the Jesuits \& friers, and what means they use to obtain them, to the prejudice of this nation and the future involving it in misery, together with some proposals to prevent the same / by a person of their own communion, who turned romanist about thirty years since (London: Printed for Henry Brome, 1680).

26 Anonymity and pseudonymity are frequent among pamphleteers (see several catalogues in Cortijo Ocaña, Herejía, and Cortijo Ocaña and Gómez Moreno, Bernardino de Mendoza). We could cite the case of John Rowland's edition of A Choice Narrative of Count Gondamor, published in 1659 and partially based on a work by Thomas Scott (the famous Newes from Spain, 1620), analysed in this volume in the chapter by Oyarbide. Or the title mentioned above published in 1680 by an unidentified 'N.N.', The arts and pernicious designs of Rome wherein is shewn what are the aims of the Jesuits \& friers, written, as the title says, 'by a person of their own communion, who turned romanist about thirty years since'. 
independence. This threat was mainly associated with Spain's Catholicism and its connection with the Jesuit order. Throughout the seventeenth century, this anxiety comes to the surface on numerous occasions. One of them was the Popish Plot, during which time an author called Salgado wrote many books that centred around Spain. For now, and while the precise identification of Salgado awaits confirmation, what is most relevant about his work is the enormous variety of registers and genres he utilized. And while the total of his production can make sense only insofar as it deals with Spanish matters depicting Spain in a rather negative vein, on many occasions his descriptions of Spain are not only accurate but betray the very likely Spanish origin of the author. That is to say, Salgado cannot help but show pride in his country of origin by depicting at times the Spanish land and its inhabitants in a rather positive light.

\section{Works Cited}

\section{Primary sources}

Anon., The High and mighty prince Charles, Prince of Wales, \&c. the manner of his arriuall at the Spanish court, the magnificence of his royall entertainement there: his happy returne, and hearty welcome both to the king and kingdome of England, the fifth of October, 1623: heere liuely and briefly described, together with certaine other delightfull passages, obseruable in the whole trauaile (London, 1623).

De la Peña, Juan Antonio, A relation of the royall festiuities and juego de cañas (a turnament of darting with reedes after the manner of Spaine) made by the King of Spaine at Madrid, the 21 of August this present yeere, 1623. To honour the espousall treaties of the illustrious Prince of Wales, with the lady Infanta Maria of Austria. Before the departure of the Prince from his court: towards the sea-side, to take shipping for his returne into England. Composed by Doctor Iuan Antonio de la Peña, natife of Madrid, and faithfully translated out of the Spanish printed copie (London: Printed [by G. Purslowe] for Henry Seyle, and are to bee sold at the Tygers Head in St Pauls Churchyard, 1623).

De la Reina, Casiodoro, Confesión de fe cristiana, hecha por ciertos españoles, los cuales, huyendo de los abusos de la Iglesia Romana y la crueldad de la Inquisición de España, dejaron su patria para ser recibidos de la Iglesia de los fieles por hermanos en Cristo (London, 1560).

Drelincourt, Charles, Les derniéres heures de Mr Drelincourt, decedé à Paris le 3. Novembre 1669: souvenez vous de vos Conducteurs, qui vous ont annoncéla Parole 
de Dieu \& imitez leur foy, considérant quelle a été la fin de leur vie (Charenton: Antoine Cellier, 1670).

The generall and particular acts and articles of the late national synod of the reformed Churches of France, assembled by the permission of the King at Charenton neare Paris, beginning the $26^{\text {th }}$ of December, 1644 . Where by the present estate of those churches, as also their doctrine and discipline may be knowne. With divers other remarkable passages, and letters from the King and Q. Regent of France, to the said synod, and of the synod to their Majesties, and other great personages (London: Printed by T.W. for G. Emerson, and are to be sold at the Swan in little Britaine, and at the blacke Beare in Pater-noster Row, 1646).

Gonsalvius Montanus, Reginaldus, Sanctae Inquisitionis Hispanicae artes aliquot detectae, ac palam traductae (Heidelberg, 1567).

N.N., The arts and pernicious designs of Rome wherein is shewn what are the aims of the Jesuits \& friers, and what means they use to obtain them, to the prejudice of this nation and the future involving it in misery, together with some proposals to prevent the same / by a person of their own communion, who turned romanist about thirty years since (London: Printed for Henry Brome, 1680).

Rosset, François de, Histoires tragiques de nostre temps où son continues les morts funestes \& lamentables de plusieurs personnes, arrives par leurs ambition, amours desreiglées, sortileges, vols, rapines \& par autres accidents divers et memorables (Lyon: Chez Nicholas Gay, 1639).

Salgado, James, A brief description of the nature of the Basilisk or Cockatrice (London, 1680 ?).

-, Carmen in Serenissimae Reginae Elisabethae Natalitia, Classem Hispanicam ab ipsa devictam, et conspirationem Papisticam antiquam et modernam (London, 1680).

—, A confession offaith in Latine / by James Salgado (London, 1680).

-, A confession of faith of James Salgado, a Spaniard, and sometimes a priest in the Church of Rome dedicated to the University of Oxford (London: Printed for William Marshall, 1681).

-, The Fryer; or, An Historical Treatise wherein he idle Lives, Vitiousness, Malice, Folly and Cruelty of the Fryes is described. In two parts: Tragical and Comical, collected out of sundry Authors, and several Languages, and caused to be translated into English. By James Salgado a Spaniard, formerly a Romish Priest (London: Printed for the Author, 1679 [and 1680]).

—, Geraldus Lisardo de regimine morali per Jacobum Salgado Hispanum [¿Gerardus Hispanus?] (Amsterdam: Apud Henricum Desbordes in de Kalverstraet, 1684 [1683]). 
-, An Impartial and Brief Description of the Plaza, or sumptuous Market Place of Madrid, and the Bull-fighting there [...] As also a large scheme, being the Lively Representation of the Order and Ornament of this Solemnity. By James Salgado a Spaniard (London: Printed by Francis Clarke for the Author, Anno Dom. 1683).

- The manners and customs of the principal nations of Europe gathered together by the particular observation ofJames Salgado, a Spaniard, in his travels through those countries; and translated into English by the authors care, anno 1684 (Edinburgh: Re-printed by Josua van Solingen and John Colmar, 1685; London: Printed by T. Snowden for the author, 1684).

—, Retorsio horridae, blasphemae et diabolicae detorsionis orationes Dom. Symboli et Decalogi in Protestantes directae, post brevem refutationem in impios illius Authores Papistas reflexa a Jacobo Salgado Hispano. Presbytero Converso (Manuscript Copy, Usoz Library).

-, The Romish Priest turn'd Protestant, with the Reasons of his Conversion, wherein the true Church is exposed to the view of Christians and derived out of the Holy Scriptures (London: Printed for Tho. Cokerill, 1679).

-, A Short Treatise of the Last Judgement. 'Qui moritur antequam moritur, non moritur quando moritur[...]'. By James Salgado a Spaniard (London: Printed by T.B. for the Author, 1684).

-, The Slaughter-House; or, a Brief Description of the Spanish Inquisition in a Method Never Before Used, With Figures Ingraved in Copper in Which is Laid Upon the Tyrrany, Insolence, Persidiousness, and Barbarous Cruelty of that Trinual (London: Printed by T.B. for the autor, 1682; London: Printed for William Marshall, 1683). -, The Slaughter-House; or, a BriefDescription of the Spanish Inquisition in a Method Never Before Used, With Figures Ingraved in Copper in Which is Laid Upon the Tyrrany, Insolence, Persidiousness, and Barbarous Cruelty of that Trinual (1683) (New York: EEBO Editions, ProQuest, 2011).

—, Symbiosis Papae et Diaboli ut et Cardinalis et Moronis cum adnexa utirusque effigie, et brevi eius Explicatione. Opera et StudioJacobi Salgado Hispani Conversi

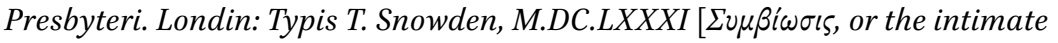
converse of Pope and Devil attended by a Cardinal and Buffon, to which is annexed The Pourtrait of each, with a brief explication thereof. By James Salgado Spaniard and converted Priest (London: Printed by Thomas Snowden, 1681; London: Printed by T.B. for the Author, 1681).

-, The true church of Christ exposed to the view of all sober Christians, from the Word of God, sound reason, and the ancient fathers / by James Salgado, a Spaniard, a converted priest (London: Printed by T.B. for the Author, 1681; London: Printed and are to be sold by William Marshall, 1683).

Stephen, John. Essayes and characters, ironicall, and instructiue. The second impression. With a new satyre in defence of common law and lawyers: mixt with 
reproofe against their common enemy. With many new characters, \& diuers other things added; \& euery thing ammended (London: Printed by E. Allde for Phillip Knight, 1615).

\section{Secondary sources}

Bossy, John, The English Catholic Community, 1570-1850 (New York: Oxford University Press, 1976).

Centro de Estudios de la Reforma, 'Protestantes en la Historia de España', http:// www.protestantes.net (last accessed: 24/12/2018).

Cortijo Ocaña, Antonio, Herejía, Inquisición y leyenda negra en el siglo XVII (James Salgado, el Hereje: Viday obra de un exsacerdote español) (Barcelona: Calambur, 2016).

— and Ángel Gómez Moreno, Bernardino de Mendoza. Propaganda, contrapropaganday leyenda negra: Comentarios de don Bernardino de Mendoça de lo sucedido en las guerras de los Países Baxos, desde el año de 1567 hasta el de 1577 (Madrid: Ministerio de Defensa, 2008).

García Pinilla, Ignacio J., 'Lectores y lectura clandestina en el grupo protestante sevillano del siglo XVI', in Lectura y culpa en el siglo XVI: Reading and Guilt in the ${ }_{16} 6^{\text {th }}$ Century, ed. by Maria José Vega and Iveta Nakládalová (Barcelona: Universitat Autònoma de Barcelona, Servei de Biblioteques de la UAB, 2012), pp. 45-62.

Holder, R. Ward, A Companion to Paul in the Reformation (Leiden: Brill, 2009).

Holmes, Peter, Resistance and Compromise: The Political Thought of Elizabethan Catholics (Cambridge: Cambridge University Press, 1982).

Maguire, Nancy Klein, 'Factionary Politics: John Crowne's Henry VI', in Culture and Society in the Stuart Restoration, ed. by Gerald MacLean (Cambridge: Cambridge University Press, 1995), pp. 80-97.

Menéndez Pelayo, Marcelino, Historia de los heterodoxos españoles (Madrid: La Editorial Católica, 1978 [1956]; Alicante: Biblioteca Virtual Miguel de Cervantes, 2003).

Pritchard, Arnold, Catholic Loyalism in Elizabethan England (Chapel Hill: University of North Carolina Press, 1979).

Roldan-Figueroa, Rady, 'Antonio del Corro and Paul as the Apostle of the Gospel of Universal Redemption', in A Companion to Paul in the Reformation, ed. by R. Ward Holder (Leiden: Brill, 2009), pp. 389-425.

Trimble, William Raleigh, The Catholic Laity in Elizabethan England (Cambridge, MA: Harvard University Press, 1964).

Wagner, Klaus, 'Erasmistas y reformistas en la Sevilla de la primera mitad del siglo XVI', in El precio de la 'invención' de América, ed. by Reyes Mate and Friedrich Niewöhner (Barcelona: Anthropos, 1992), pp. 125-141. 
—, 'Los maestros Gil de Fuentes y Alonso de Escobar y el círculo de luteranos de Sevilla', Hispania Sacra 28 (1975), pp. 239-247.

Usoz y Río, Luis, and Benjamin B. Wiffen, eds, Reformistas antiguos españoles, 20 vols (London, 1848-1870).

\section{About the Author}

Antonio Cortijo Ocaña is Professor of Spanish Medieval and Early Modern Literature at the Department of Spanish and Portuguese of the University of California (Santa Barbara). He analyses in his research the ideological structures and tensions that have forged the modern period across the Atlantic and across the languages and cultures of the Iberian Peninsula. He deals with issues such as nation building, power and ideology, religion and economy in the late medieval period through the eighteenth century, as well as with the larger topic of the relevance of humanism in the creation of the modern nations. He has produced five monographs on war, history and ideology in the early modern period dealing with the wars of religion of the sixteenth and seventeenth centuries, three books related to the Black Legend, as well as several other monographs, editions, and more than 150 articles. 